\title{
Funding announced for the Middle East Cancer Consortium
}

Initial funding for the Middle East Cancer Consortium (MECC) has been announced by the National Institutes of Health and the National Cancer Institute (NCI). For fiscal year $1997 / 98$, the international MECC Board of Governors will receive $\$ 300,000$ for the smallgrants research program, $\$ 100,000$ for research workshops and $\$ 500,000$ for joint regional cancer registration, the premier project of the MECC.

The small-grants program is now soliciting research proposals in several areas of cancer research including clinical, epidemiological, basic and sociopsychological investigations. Proposals from at least two scientists from different member states (Cyprus, Egypt, Israel, Jordan and the Palestinian Authority) will receive preference. Each may receive up to $\$ 15,000$ per two-year project. An extramural panel from the NCI program will rank grant proposals, and the MECC Board will select the successful applicants.

The NCI Office of International Affairs has also set aside $\$ 1.25$ million support over five years for training programs so that designated MECC scientists and physicians can train in the US or other MECC countries, or in NCI institutions worldwide. It is hoped that all financial responsibilities will be transferred to member countries over the next few years.

RAE MAN JERUSALEM

\section{Specialized centers for children's health research}

The deadline for letter-of-intent applications from US universities, medical schools and research institutions wishing to become one of six federally funded centers investigating environmental factors that affect children's health, closed yesterday. A team of government and independent experts will now evaluate research proposals, and the centers are expected to be established in September 1998.

Successful groups will receive a share of the $\$ 10$ million funding for the program provided by the Department of

Health and Human Services (HHS) and the Environment Protection Agency (EPA). The Centers for Disease Control has also pledged a donation.

The initiative is part of a task-force cochaired by Donna Shalala (HHS Secretary) and Carol Browner (EPA Administrator), which was established in response to President Clinton's Executive Order - issued in April - to address environmental health and safety risks to the nation's children.

K.B.

\section{$\$ 7.8$ million for rheumatoid arthritis research}

In what is being billed as the "largest such effort in the world," 12 US research centers are to form a new consortium that will search for genes which determine susceptibility to rheumatoid arthritis. The North American Rheumatoid Arthritis Consortium (NARAC) will be funded for a fiveyear period by the National Institute of Arthritis and Musculoskeletal and Skin Diseases (\$5.4 million), the National Institute of Allergy and Infectious Diseases (\$1.25 million), the American Arthritis Foundation ( $\$ 1$ million) and the NIH Office of Research on Women's Health $(\$ 150,000)$.
This is apparently the first time that the Arthritis Foundation has funded a collaborative research effort. NARAC plans to collect medical information and genetic material from 1,000 families nationwide, in which two or more siblings have been diagnosed with the disease: studies shows that if a person has rheumatoid arthritis, his or her siblings are 2-10 times more likely to develop the disease than the rest of the population. Peter Gregersen of North Shore University Hospital, New York, will head the project.

K.B.
Fisher settles with the University of Pittsburgh and the $\mathrm{NCI}$

Bernard Fisher, the cancer surgeon who pioneered the practice of lumpectomy, has settled a lawsuit against the University of Pittsburgh for wrongfully dismissing him as head of the National Surgical Adjuvant Breast and Bowel Project, which he had headed for 27 years. The case was settled just days before a scheduled trial. The university agreed to pay Fisher $\$ 2.75$ million for damage to his reputation and First Amendment rights. The National Cancer Institute ( $\mathrm{NCl}$ ), which sponsors the breast cancer study, agreed to pay $\$ 300,000$ toward his legal bills.

Fisher's management of the multicenter clinical trial was called into question in 1994 when the Chicago Tribune reported that a

handful of patients at a hospital in Canada were recruited when they were in fact ineligible because their cancers had been diagnosed more than 30 days before they were enrolled. Fisher reported this technicality to $\mathrm{NCl}$ officials but did not issue an official statement for fear of needlessly alarming the public as to the validity of the study as a whole. He felt that the small amount of data erroneously included in no way changed the overall conclusion that lumpectomy is as valuable as total mastectomy in many cases. However, his actions were considered fraudulent.

After being stripped of his position as principal investigator and forbidden to play any administrative role in the study, Fisher sued the university for acceding to the $\mathrm{NCl}^{\prime}$ s pressure to remove him as director of the project.

Following a protracted 3-year investigation, the Office of Research Integrity concluded that Fisher was not guilty of misconduct in March of this year.

The University publicly apologized to Fisher who says he is relieved that both they and the $\mathrm{NCl}$ have finally admitted no wrong-doing on his part. A tenured Distinguished Service Professor who works without salary, Fisher (78) says, "I do not plan to retire. I plan to get on with my work."

B.J.C. 